Jurnal Keperawatan Silampari

Volume 5, Nomor 1, Desember 2021

e-ISSN: 2581-1975

p-ISSN: 2597-7482

DOI: https://doi.org/10.31539/jks.v5i1.3066

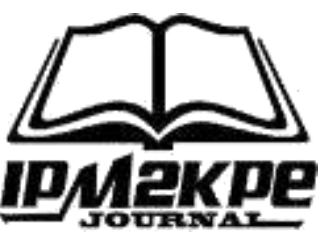

\title{
PERAN TENAGA KESEHATAN DAN KELUARGA TERHADAP KEHAMILAN REMAJA
}

\author{
Saleh $^{1}$, Misnaniarti ${ }^{2}$, Haerawati Idris ${ }^{3}$, Samwilson Slamet ${ }^{4}$ \\ Indah Yuliana ${ }^{5}$ \\ Universitas Sriwijaya ${ }^{1,2,3,5}$ \\ Universitas Bengkulu ${ }^{4}$ \\ br.saleh038@gmail.com ${ }^{1}$
}

\begin{abstract}
ABSTRAK
Penelitian ini bertujuan untuk mengidentifikasi dan menganalisis peran tenaga kesehatan dan keluarga dengan kejadian kehamilan usia remaja di wilayah Kabupaten Kepahiang tahun 2021. Penelitian ini merupakan penelitian deskriptif kuantitatif menggunakan desain cross sectional. Hasil analisis univariat menunjukkan bahwa sebagian besar responden berumur $30-34$ tahun $(25,8 \%)$, terdapat 53 orang $(60,2 \%)$ yang mengalami kehamilan di usia remaja $(<19$ tahun), sebagian besar respoden 53 orang $(60,2 \%)$ mendapatkan peran keluarga yang cukup, sebanyak 66 orang $(75 \%)$ menyatakan bahwa peran tenaga kesehatan termasuk dalam kategori baik. Responden yang menyatakan memiliki peran keluarga dalam kategori cukup dari 53 terdapat sebagian besar 39 orang atau 73,6\% yang mengalami kehamilan usia remaja, responden yang menyatakan peran tenaga kesehatan dalam kategori cukup hampir seluruh responden atau sebanyak 15 orang $(78,9 \%)$ yang mengalami kehamilan usia remaja. Analisis data dengan uji statistik chi-square didapatkan (p-value) $(0,125)$. Variabel peran orang tua dengan kejadian kehamilan pada remaja dengan $p$ value $=$ 0,000 . Simpulan, tidak terdapat hubungan peran tenaga kesehatan dengan kejadian kehamilan usia remaja di Kabupaten Kepahiang tahun 2021. Ada hubungan antara peran orang tua responden dengan kejadian kehamilan remaja dan tidak ada hubungan antara peran tenaga kesehatan dengan kejadian kehamilan remaja.
\end{abstract}

Kata Kunci: Kehamilan, Keluarga, Remaja Tenaga Kesehatan

\section{ABSTRACT}

This study aims to identify and analyze the role of health workers and families in teenage pregnancy in the Kepahiang District in 2021. This study is a quantitative descriptive study using a cross-sectional design. The results of the univariate analysis showed that most of the respondents were aged 30-34 years (25.8\%), there were 53 people (60.2\%) who experienced pregnancy in their teens (<19 years), most of the respondents were 53 people $(60.2 \%)$ had sufficient family roles, as many as 66 people $(75 \%)$ stated that the part of health workers was included in the excellent category. Respondents who indicated that they had a family role in the superb category out of 53 mainly were 39 people or $73.6 \%$ who experienced teenage pregnancy, respondents who stated the position of health workers in the excellent category were almost all of the respondents or as many as 15 people (78.9\%) who experienced teenage pregnancy. Data analysis with a chi-square statistical test was obtained (p-value) (0.125). The variable of the role of parents and the incidence of 
pregnancy in adolescents with p-value $=0.000$ In conclusion, there is no relationship between the part of health workers and the incidence of teenage pregnancy in Kepahiang Regency in 2021. There is a relationship between the role of the respondent's parents with the incidence of adolescent pregnancy, and there is no relationship between the part of health workers with the incidence of teenage pregnancy.

Keywords: Pregnancy, Family, Adolescent Health Workers

\section{PENDAHULUAN}

Angka Kematian Ibu (AKI) merupakan salah satu indikator untuk melihat keberhasilan upaya kesehatan ibu. AKI adalah rasio kematian ibu selama masa kehamilan, persalinan dan nifas yang disebabkan oleh kehamilan, persalinan, dan nifas atau pengelolaannya tetapi bukan karena sebab-sebab lain seperti kecelakaan atau terjatuh di setiap 100.000 kelahiran hidup (Pemerintah Provinsi Bengkulu, 2020).

Salah satu penyebab kematian ibu adalah kehamilan risiko tinggi diantaranya kehamilan remaja ( $<20$ tahun). Sebanyak 10,3\% kehamilan usia $<20$ tahun menyebabkan kematian pada ibu secara tidak langsung. Organ reproduksi remaja yang belum matang tidak siap menerima kehamilan sehingga berdampak buruk terhadap ibu hamil sendiri maupun janin yang dikandung. Rata-rata usia pernikahan pertama diperkotaan adalah 19 tahun dan dipedesaan lebih rendah yaitu 17 tahun. Pada perempuan kelompok usia 15-19 tahun 2,8\% diantaranya telah hamil di usia 15 tahun dan kelompok usia 20-24 tahun didapatkan 24,2\% telah hamil pada usia 18 tahun. Jumlah kehamilan remaja dipedesaan lebih besar dibandingkan dengan di daerah perkotaan (Pemerintah Provinsi Bengkulu, 2020).

Masa remaja adalah peralihan dari masa anak dengan masa dewasa yang mengalami perkembangan semua aspek atau fungsi untuk memasuki masa dewasa. Masa remaja berlangsung antara umur 12-21 tahun bagi wanita dan 13-22 tahun bagi pria. Kehamilan remaja merupakan masalah yang sering terjadi pada remaja saat ini. Kebanyakan dari mereka belum mendapatkan penyuluhan tentang kesehatan dan resiko kehamilan di usia muda (Fatkhiyah et al., 2020). Dampak dari kehamilan pada usia remaja adalah abortus, kehamilan yang beresiko untuk terjadinya pre-eklamsia, anemia, bayi prematur, Bayi Berat Lahir Rendah (BBLR), kematian bayi, kanker alat reproduksi, karena pada usia 12-17 tahun rentan terjadi perubahan sel dalam mulut rahim (Widyaningsih, 2021).

Berdasarkan data Dinas Kesehatan Kabupaten Kepahiang, proporsi kejadian kehamilan usia remaja pada tahun 2019 sampai dengan tahun 2020 cenderung terjadi peningkatan, hal ini ditunjukan dengan data persetase jumlah kehamilan remaja pada tahun 2019 sebesar $65 \%$ dan meningkat menjadi 70\% pada tahun 2020. Berdasarkan data yang diperoleh dari Perkumpulan Keluarga Berencana Indonesia (PKBI) Bengkulu tahun 2020 yang melaporkan persentase kasus kehamilan remaja terbanyak terjadi di Kabupaten Kepahiang yaitu dengan persentase $65 \%$, disusul Kabupaten Rejang Lebong dengan persentase 50\%, Kabupaten Lebong 45\%, Kabupaten Bengkulu Selatan 40\%, dan terakhir Kabupaten Kaur dengan persentase 37\% (PKBI, 2020).

Data dan fakta di atas menunjukkan belum efektifnya pelaksanaan program dan strategi yang telah dilaksanakan oleh pemerintah khususnya di Kabupaten Kepahiang, mengingat beberapa program telah dilaksanakan antara lain program Genre (Generasi Berencana), kegiatan posyandu remaja, Pelayanan Kesehatan Peduli Remaja (PKPR) dan program-program lainnya seperti pelaskanaan sosialisasi Pendewasaan Usia Perkawinan (PUP) yang diselenggarakan oleh Badan Pemberdayaan Perempuan dan Masyarakat (BPPM) Kabupaten Kepahiang. PUP adalah upaya untuk meningkatkan usia perkawinan 
pertama, sehingga diharapkan usia perkawinan pertama pada perempuan minimal 20 tahun dan 25 tahun pada laki-laki (Dinkes Kepahiang, 2019).

Penelitian terdahulu telah banyak mengupas tentang kejadian dan dampak kehamilan pada remaja, namun belum ada yang menganalisis peran tenaga kesehatan dan keluarga pada kehamilan di usia remaja masa pandemi COVID-19.

\section{METODE PENELITIAN}

Penelitian ini merupakan jenis penelitian deskriptif kuantitatif dengan menggunakan desain cross sectional. Lokasi penelitian di seluruh Puskesmas di Kabupaten Kepahiang dengan waktu pelaksanaan penelitian dilaksanakan pada bulan Oktober 2021.

Populasi dalam penelitian ini adalah seluruh ibu hamil yang tercatat dalam laporan Kegiatan Kesehatan Ibu dan Anak Dinas Kesehatan Kabupaten Kepahiang pada bulan September 2021, sebanyak 2.618 orang. Pengambilan sampel pada penelitian ini menggunakan teknik purposive sampling dan menggunakan kriteria inklusi sehingga didapatkanlah jumlah sampel sebanyak 88 orang. Teknik pengumpulan data dengan cara menyebarkan instrumen berupa kuesioner yang telah dimodifikasi. Sebelum melakukan pengumpulan data, peneliti meminta persetujuan responden untuk menjadi subjek penelitian dengan menandatangani pernyataan persetujuan bersedia menjadi subjek penelitian lalu data dianalisis menggunakan uji statistik chi square.

\section{HASIL PENELITIAN}

\section{Analisis Univariat}

Tabel. 1

Distribusi Frekuensi

Kejadian Kehamilan Usia Remaja

\begin{tabular}{lcc}
\hline \multicolumn{1}{c}{ Kehamilan Usia Remaja } & Frekuensi & $(\%)$ \\
\hline Kehamilan Usia Remaja & 53 & 60,2 \\
Kehamilan Tidak Usia Remaja & 35 & 39,8 \\
\hline \multicolumn{1}{c}{ Jumlah } & 88 & 100 \\
\hline
\end{tabular}

Berdasarkan tabel 1 kejadian kehamilan remaja di Kabupaten Kepahaiang berdasarkan hasil penelitian ini terlihat dari tabel 1 di atas, dimana menunjukkan dari 88 orang responden terdapat sebagian besar atau terdapat sebanyak 53 orang $(60,2 \%)$ yang mengalami kehamilan dimasa remaja $(<19$ tahun).

Tabel. 2

Distribusi Frekuensi Peran Keluarga terhadap Kejadian Kehamilan Usia Remaja

\begin{tabular}{lccc}
\hline & Peran Keluarga & Frekuensi & $(\%)$ \\
\hline Kurang & & 21 & 23,9 \\
Cukup & 53 & 60,2 \\
Baik & & 14 & 15,9 \\
\hline & Jumlah & 88 & 100 \\
\hline
\end{tabular}

Berdasarkan tabel 2 menunjukkan bahwa berdasarkan analisis data distribusi tentang peran keluarga responden terhadap kejadian kehamilan di masa remaja di Kabupaten Kepahiang, diketahui dari 88 orang responden terdapat sebagian besar respoden atau sebanyak 53 orang $(60,2 \%)$ responden menyatakan memiliki peran keluarga yang cukup. 
Tabel. 3

Distribusi frekuensi Peran Tenaga Kesehatan terhadap Kejadian Kehamilan Usia

\begin{tabular}{lccc}
\hline & Kehamilan Usia Remaja & Frekuensi & $(\%)$ \\
\hline Kurang & 3 & 3,4 \\
Cukup & 19 & 21,6 \\
Baik & Jumlah & 66 & 75 \\
\hline & & 88 & 100 \\
\hline
\end{tabular}

Berdasarkan tabel 3 diketahui bahwa peran tenaga kesehatan terhadap kejadian pernikahan dini di Kabupaten Kepahiang tahun 2021 diperoleh hasil bahwa sebagian besar responden atau sebanyak 66 orang $(75 \%)$ menyatakan bahwa peran tenaga kesehatan termasuk dalam kategori baik, sedangkan pada kategori cukup diperoleh sebagian kecil responden atau sebanyak 3 orang $(3,4 \%)$ dan 19 orang $(21,6 \%)$ menyatakan bahwa peran tenaga kesehatan termasuk dalam kategori cukup.

\section{Analisa Bivariat}

Tabel. 4

Hubungan Peran Keluarga

terhadap Kejadian Kehamilan Usia Remaja

\begin{tabular}{|c|c|c|c|c|c|c|c|}
\hline \multirow{3}{*}{$\begin{array}{c}\text { Peran } \\
\text { Keluarga }\end{array}$} & \multicolumn{4}{|c|}{ Kehamilan Usia Remaja } & \multirow{3}{*}{ Total } & \multirow{3}{*}{$\%$} & \multirow{3}{*}{$P$} \\
\hline & \multicolumn{2}{|c|}{ Hamil Usia Remaja } & \multicolumn{2}{|c|}{ Tidak Hamil Usia Remaja } & & & \\
\hline & $\mathrm{N}$ & $\%$ & $\mathrm{~N}$ & $\%$ & & & \\
\hline Kurang & 6 & 28,6 & 15 & 71,4 & 21 & 100 & \\
\hline Cukup & 39 & 73,6 & 14 & 26,4 & 53 & 100 & 0,02 \\
\hline \multirow[t]{2}{*}{ Baik } & 8 & 57,1 & 6 & 42,9 & 14 & 100 & \\
\hline & 53 & 60,2 & 35 & 39,8 & 88 & 100 & \\
\hline
\end{tabular}

Berdasarkan tabel 4 menunjukkan bahwa sebagian besar responden yang menyatakan memiliki peran keluarga dalam kategori cukup sebanyak 39 orang mengalami kehamilan usia remaja, sedangkan dari 14 orang responden dengan peran keluarga dengan kategori baik terdapat 8 orang yang mengalami kehamilan usia remaja. Analisis data dengan uji statistik chi-square diperoleh $p$ value $=0,02<0,05$, maka terdapat hubungan peran keluarga dengan kejadian kehamilan usia remaja di Kabupaten Kepahiang Tahun 2021.

Tabel. 5

Hubungan Peran Tenaga Kesehatan terhadap Kejadian Kehamilan Usia Remaja

\begin{tabular}{|c|c|c|c|c|c|c|c|}
\hline \multirow{3}{*}{$\begin{array}{l}\text { Peran Tenaga } \\
\text { Kesehatan }\end{array}$} & \multicolumn{4}{|c|}{ Kejadian Kehamilan remaja } & \multirow{3}{*}{ Total } & \multirow{3}{*}{$\%$} & \multirow{3}{*}{$P$} \\
\hline & \multicolumn{2}{|c|}{$\begin{array}{l}\text { Hamil Usia } \\
\text { Remaja }\end{array}$} & \multicolumn{2}{|c|}{$\begin{array}{c}\text { Tidak Hamil Usia } \\
\text { Remaja }\end{array}$} & & & \\
\hline & $\mathrm{N}$ & $\%$ & $\mathrm{~N}$ & $\%$ & & & \\
\hline Kurang & 1 & 33,3 & 2 & 66,7 & 3 & 100 & \\
\hline Cukup & 15 & 78,9 & 4 & 21,1 & 19 & 100 & 0,125 \\
\hline Baik & 37 & 56,1 & 29 & 43,9 & 66 & 100 & \\
\hline Total & 53 & 60,2 & 35 & 39,8 & 88 & 100 & \\
\hline
\end{tabular}


Berdasarkan tabel 5 menunjukkan bahwa responden yang menyatakan peran tenaga kesehatan dalam kategori baik terdapat sebagian besar atau sebanyak 37 orang $(56,1 \%)$ yang mengalami kehamilan usia remaja dan dari 19 orang responden yang menyatakan peran tenaga kesehatan dalam kategori cukup hampir seluruh responden atau sebanyak 15 orang $(78,9 \%)$ yang mengalami kehamilan usia remaja. Analisis data dengan uji statistik chi-square diperoleh $p$ value $=0,125>0,05$ artinya tidak terdapat hubungan peran tenaga kesehatan dengan kejadian kehamilan usia remaja di Kabupaten Kepahiang Tahun 2021.

\section{PEMBAHASAN}

\section{Kejadian Kehamilan Usia Remaja}

Dalam penelitian ini ditemukan hasil $60,2 \%$ responden mengalami kehamilan usia remaja, angka ini menunjukkan tingginya angka fertilitas remaja di Kabupaten Kepahiang. Kejadian wanita hamil usia remaja masih sangat tinggi. Kehamilan pada usia remaja perlu dicegah sedini mungkin. Berbagai upaya pencegahan seperti pendidikan kesehatan reproduksi perlu dilakukan baik oleh orang tua, guru di sekolah maupun oleh tenaga kesehatan sehingga meningkatkan pemahaman remaja terkait kesehatan reproduksi. Pemahaman yang baik tentang kesehatan reproduksi pastinya akan membantu mencegah kehamilan usia remaja (Zakiah, 2020).

Kehamilan remaja di Indonesia dipengaruhi oleh berbagai faktor. Pada penelitian yang dilakukan oleh Aminatussyadiah et al., (2020) menunjukkan bahwasannya paparan media informasi dan juga tingkat pendidikan memiliki kontribusi akan kejadia kehamilan pada remaja. Media informasi memiliki kontribusi yang cukup besar dalam mengenalkan konten seksual kepada remaja. Baik melalui film, game dan gambar-gambar yang memiliki muatan pornografi. Selain itu di televisi pun banyak disiarkan sinetron yang mampu menjerumuskan para remaja akan kegiatan-kegiatan negatif. Tontonan semacam inilah yang mampu menyebabakna rasa penasaran pada diri remaja untuk mencoba melakukan yang berbau seksualitas, mulai dari pelukan, saling mencium hingga melakukan intercourse.

Berdasarkan data dari Dinas Kesehatan Kabupaten Kepahiang sampai dengan bulan September tahun 2021 tercatat sebanyak 118.581 orang sasaran remaja dan sebanyak 158 orang remaja $(0,13 \%)$ yang mengalami kehamilan usia remaja (Dinkes Kepahiang, 2019). Bahkan menurut BKKBN pada 2020 telah merilis angka kelahiran wanita kelompok umur 15 hingga 19 tahun sebesar 50,9/1000 kelahiran hidup. Angka tersebut meningkat dari sebelumnya yang hanya 49/1000 kelahiran hidup berdaarkan data SDKI, 2017 (BKKBN, 2021).

Pernikahan usia anak terjadi disebabkan oleh terhentinya pendidikan, faktor ekonomi, tidak mau menjadi beban orang tua, kurangnya pengetahuan tentang dampak menikah usia anak, serta tidak adanya aktifitas lain setelah putus sekolah (Pratiwi et al., 2019). Riwayat kehamilan remaja pada keluarga dan usia menikah merupakan variabel yang berhubungan dengan kejadian kehamilan remaja. Responden yang berpendidkan rendah memiliki peluang 20,8 kali dan riwayat kehamilan remaja pada keluarga memiliki peluang 14,9 kali, responden yang menikah pada usia $<20$ tahun memiliki peluang 12,1 kali lebih tinggi untuk terjadi kehamilan remaja dan responden dengan pemahaman yang kurang baik terkait penggunaan kondom memiliki peluang 5,9 kali lebih tinggi untuk terjadi kehamilan remaja (Setyaningsih \& Sutiyarsih, 2020).

Konsekuensi akibat kehamilan dan kelahiran remaja tidak hanya berdampak pada tingkat individu, namun juga berimbas ditingkatan sosial dan global. Pada tingkatan sosial masyarakat, adanya hubungan yang kuat antara melahirkan pada usia remaja dengan 
rendahnya tingkat pendidikan membawa dampak negatif pada posisi sosial mereka di masyarakat. Secara individual, fertilitas remaja dikaitkan dengan permasalahan kesehatan ibu dan anak yang merugikan, termasuk sulitnya persalinan, berat badan lahir rendah, keterlambatan pertumbuhan janin. Secara global, pertumbuhan penduduk akan lebih cepat ketika seorang perempuan memiliki anak pertama mereka pada usia remaja serta akan memperpanjang masa reproduksi yang berkonsekuensi pada peningkatan fertilitas (Setyaningsih \& Sutiyarsih, 2020). Tingginya angka kejadian kehamilan remaja pada penelitian ini didukung fakta di lapangan, sejak pandemi COVID-19 menyebabkan adanya kebijakan pemerintah untuk membatasi aktifitas di luar rumah dengan menerapkan physical distancing untuk memutus penyebaran COVID-19.

Masyarakat dihimbau untuk tidak melakukan kontak langsung dengan orang lain serta menghindari kerumunan dan tidak mendatangi acara-acara yang menghadirkan massa yang banyak. Seperti halnya aktifitas-aktifitas belajar, bekerja dan beribadah, semua dilaksanakan dari rumah dan remaja merupakan kelompok yang paling terdampak karena adanya perubahan pola sekolah menjadi pembelajaran jarak jauh secara daring (Pradnyani et al., 2020).

Kondisi tersebut menjadikan para pelajar dan mahasiswa dipaksa harus belajar di rumah dimana sebagian besar tidak terbiasa melakukan hal tersebut. Untuk jangka waktu pendek hal tersebut tentunya tidak menjadi masalah, tetapi dalam jangka panjang akan membuat anak menjadi bosan dan tertekan, sehingga hal tersbut menyebkan anak menjadi terganggu kesehatan mentalnya, mulai dari cemas sampai kasus depresi (Purwanto et al., 2020). Dengan sekolah diliburkan belajar secara tatap muka, itu menimbulkan kebosanan pada anak-anak sehingga mereka malah lebih memilih menghabiskan waktu dengan berselancar di dunia maya, pacaran yang berakhir dengan menikah pada usia masih sekolah (Ningsih \& Rahmadi, 2020).

Penelitian Pradnyani et al., (2020) menunjukkan bahwa Secara deskriptif terjadi perubahan sikap terkait perilaku seksual remaja sebelum dan selama COVID-19. Penting adanya sosialisasi tentang PKPR kepada remaja sangat mempengaruhi pengetahuan remaja tentang PKPR. Adanya peningkatan pengetahuan remaja tentang PKPR setelah diberikan penyuluhan. Perubahan pengetahuan dan sikap salah satunya dapat dipengaruhi melalui pendidikan kesehatan beruba pemberian penyuluhan kesehatan. Remaja mendapatkan pembelajaran dan informasi dari penyuluhan yang dilakukan sehingga menghasilkan suatu perubahan (Sartika et al., 2021).

Memberikan pendidikan seksual remaja melalui POSKESJA dapat membantu remaja mengenal kesehatan reproduksi lebih dini sebagai upaya promotif dan prevemtif, sehingga dapat mencegah remaja terjerumus dalam pergaulan bebas dan penyimpangan perilaku kesehatan (Febriawati et al., 2019).

\section{Hubungan Peran Keluarga terhadap Kejadian Kehamilan Usia Remaja}

Hasil analisis data statistik menunjukkan ada hubungan antara peran keluarga terhadap kejadian kehamilan remaja. Penelitian ini juga juga sejalan dengan hasil penelitian Musni \& Malka (2020) dengan hasil penelitian ada hubungan peran orang tua dengan kejadian kehamilan pada remaja dengan $p$ value $=0,000$.

Peran orang tua sangat diperlukan dalam memberitahukan kepada remaja terhadap resiko kehamilan dini pada usia remaja. Orang tua harus menjadi orang yang terdekat dengan remaja. Jika orang tua dekat dengan remaja, maka otomatis orang tua dapat melihat kemungkinan kesulitan yang dialami remaja. Dalam hal ini orang tua harus mampu menjadi konsultan bagi remaja. Apabila orang tua bersikap terbuka dan informatif 
mengenai seksualitas, maka remaja lebih besar kemungkinan menunda melakukan hubungan intim dan lebih kecil kemungkinan mengalami kehamilan remaja.

Status pekerjaan orang tua akan mempengaruhi terbentuknya pola komunikasi di dalam keluarga, dimana orang tua yang bekerja cenderung akan lebih sulit untuk memberikan perhatian dan membina pola komunikasi dengan keluarga yang lain termasuk anak. Menurut BPS Kabupaten Kepahiang (2021) menyatakan bahwa status pekerjaan utama penduduk Kabupaten Kepahiang 28,9 \% adalah dengan berusaha dibantu dengan buruh tetap/buruh tidak tetap. Berdasarkan pengamatan di lokasi penelitian sebagian besar pekerjaan orang tua adalah sebagai petani dan buruh tani pada perkebunan kopi, dimana jam kerja dimulai dari pagi hingga sore hari dan waktu yang tersedia untuk berkumpul dengan keluarga adalah di malam hari. Remaja yang kurang kasih sayang dari orang tua lebih cenderung mencari keintiman di luar.

Kondisi pandemi COVID-19 juga memberikan dampak pada kondisi keharmonisan keluarga, berdasarkan survei yang dilakukan oleh Badan Koordinasi Keluarga Berencana Nasional (BKKBN) pada tahun 2020 terkait kondisi keluarga pada masa pandemi COVID 19, dengan hasil survei adanya perubahan hidup keluarga dalam pekerjaan, keuangan, kecukupan makanan dengan kondisi semakin memburuk pada masa pandemi COVID-19 cukup mengkhawatirkan, sedangkan untuk kondisi kesehatan, interaksi keluarga dan komunikasi dalam keluarga besar tidak mengalami banyak perubahan sebelum maupun sesudah pandemi. Terkait interaksi/komunikasi dengan keluarga besar, kondisi yang semakin memburuk akan mengurangi dukungan sosial jika keluarga inti membutuhkan bantuan.

Dukungan orang tua secara moril dan finansial sangat berperan dalam proses kehamilan hingga melahirkan dan membesarkan anak, sedangkan bentuk dukungan dari tenaga atau dinas kesehatan berupa pemberian motivasi, konseling dan bimbingan bagaimana menjalankan kehamilan dengan baik. Remaja putri harus mendapatkan pemahaman mengenai kesehatan reproduksi sejak dini, apabila sudah telanjur menikah usia muda, diupayakan menunda kehamilan sampai batas umur aman secara reproduksi dan emosisonal (Maisya \& Susilowati, 2017).

Pola makan ibu hamil juga menjadi hal penting yang harus diperhatikan, faktor lain yang mempengaruhi pola makan ibu hamil yang tidak sehat diantaranya tingkat pendidikan sehingga pengetahuan ibu kurang akan pola makan sehat bagi ibu hamil, status ekonomi yang tidak mampu untuk memenuhi kebutuhan, ibu mengalami mual muntah yang menyebabkan tidak mau makan dan faktor lingkungan (Mariana et al., 2018).

Berdasarkan penelitian yang dilakukan oleh Padila et al., (2021) didapatkan bahwa ibu usia remaja yang melahirkan di masa pandemi COVID-19 menderita cemas tingkat sedang dan minimnya dukungan keluarga saat melahirkan serta menerima perlakuan dengan kualitas akses pelayanan kesehatan yang kurang.

\section{Hubungan Peran Tenaga Kesehatan terhadap Kejadian Kehamilan Usia Remaja}

Hasil analisis data statistik dengan mengggunakan uji chi square untuk mengetahui hubungan peran tenaga kesehatan terhadap kejadian kehamilan remaja menunjukkan tidak ada hubungan. Hasil penelitian menunjukkan tidak terdapat terdapat hubungan dari peran tenaga kesehatan terhadap pencegahan kehamilan usia remaja. Oleh karena itu, peran tenaga kesehatan perlu ditingkatkan untuk dapat mencegah terjadinya kehamilan di usia dini baik secara langsung maupun tidak langsung melalui perang orang tua, teman sebaya dan motivasi yang baik agar remaja tersebut menjauhi perilaku negatif yang dapat mengarah pada perilaku seks pra nikah dan menyebabkan kehamilan di masa remaja. 
Begitupun sebaliknya apabila peran tenaga kesehatan tidak ditingkatkan maka usaha yang sudah dilakukan dalam mencegah terjadinya kehamilan di usia dini akan sia-sia.

Dalam penelitian ini terdapat sebagian besar responden atau sebanyak $56,1 \%$ yang menyatakan peran tenaga kesehatan dalam kategori baik akan tetapi mengalami kehamilan usia remaja. Berdasarkan indikator peran tenaga kesehatan yaitu sebagai komunikator, motivator, fasilitator dan konselor, dan dari hasil analisis data jawaban responden atas pertanyaan kuesioner diperoleh rata-rata persentase jawaban responden terendah adalah pada peran petugas sebagai fasilitator.

Penyebab permasalahan kesehatan remaja juga dapat terjadi karena kurangnya akses pelayanan kesehatan remaja, yang meliputi tidak adanya fasilitas, remaja tidak tahu jika dirinya bermasalah, remaja tidak tahu ada fasilitas, remaja tahu tapi tidak terakses (waktu, biaya, datang harus dengan orang tua), remaja tahu tapi tidak mau (waktu tunggu lama, petugas tidak friendly.

Pada masa pandemi COVID-19 juga memberikan dampak pada pelaksanaan peran dan pelayanan khususnya dalam pelaksanaan perannya sebagai komunikator dan konselor yang memungkinkan untuk adanya aktifitas tatap muka. Selain itu permasalahan lain yang dihadapi petugas kesehatan dalam menjalankan perannya adalah dengan keterbatasan dana dan fasilitas, hal ini juga terkait dengan kebijakan untuk diterapkannya kebijakan refocussing dana kegiatan dan program yang terfokus pada upaya pengendalian dan pencegahan penularan COVID-19.

Berdasarkan hasil penelitian yang dilakukan oleh Diniyati \& Jayatmi (2017) didapatkan bahwa pengaruh tenaga kesehatan terhadap perilaku pernikahan dini lebih tinggi dari pada variabel yang lainnya. Sehingga perlu adanya peningkatan dukungan dan peran aktif tenaga kesehatan dalam upaya peningkatan pengetahuan remaja tentang kesehatan reproduksi. Peran tenaga kesehatan sangat dibutuhkan, terutama melakukan konseling dan penyuluhan kepada anak remaja tentang kesehatan reproduksi dan dampak dari akibat serta resiko dari kehamilan usia remaja tersebut (Lestari et al., 2019).

\section{SIMPULAN}

Sebagian besar responden mengalami kehamilan dimasa remaja. Tidak terdapat hubungan peran tenaga kesehatan dengan kejadian kehamilan usia remaja. Ada hubungan antara peran orang tua dengan kejadian kehamilan pada remaja.

\section{SARAN}

Bagi tenaga kesehatan yang ada dikomunitas dianjurkan optimalisasi peran sebagai konselor kepada orang tua dan remaja melalui UKS sekolah dalam upaya peningkatan pengetahuan remaja tentang kesehatan reproduksi dan memberikan edukasi serta bekal bagi remaja usia sekolah agar terhindar dari pergaulan bebas yang berdampak pada terjadinya kehamilan remaja dan pernikahan dini.

\section{DAFTAR PUSTAKA}

Aminatussyadiah, A., Wardani, S. F. P., \& Rohmah, A. N. (2020). Media informasi dan tingkat pendidikan berhubungan dengan kehamilan remaja Indonesia. Jurnal Kebidanan, 9(2), 173. https://doi.org/10.26714/jk.9.2.2020.173-182

Diniyati, L. S., \& Jayatmi, I. (2017). Pengaruh Empat Variabel terhadap Perilaku Pernikahan Dini Perempuan Pesisir. Jurnal Ilmiah Kesehatan, 16(2), 14-22. https://doi.org/10.33221/jikes.v16i2.9 
Dinkes Kepahiang, D. (2019). Dinas Kesehatan Kepahiang Arsip. https://kepahiang.progres.id/read/dinas-kesehatan-kepahiang

Fatkhiyah, N., Masturoh, M., \& Atmoko, D. (2020). Edukasi Kesehatan Reproduksi Remaja. Jurnal Abdimas Mahakam, 4(1), 84-89. https://doi.org/10.24903/jam.v4i1.776

Febriawati, H., Padila, P., \& Anita, B. (2019). Pendidikan Seksual Remaja melalui Poskesja. Jurnal Pengabdian Masyarakat Bumi Raflesia, 1(1). https://doi.org/10.36085/jpmbr.v1i1.193

Lestari, R. M., Paramita, A., \& Bella, B. (2019). Analisi Hubungan Status Ekonomi dan Budaya dengan Kejadian Kehamilan Usia Remaja di Pukesmas Pahandut Kota Palangkaraya. Proceeding of Sari Mulia University Midwifery National Seminars. https://doi.org/0.33859/psmumns.v0i1.45

Maisya, I., \& Susilowati, A. (2017). Peran Keluarga dan Lingkungan terhadap Psikososial Ibu Usia Remaja. Jurnal Kesehatan Reproduksi, 8(2), 163-173. http://ejournal.litbang.kemkes.go.id/index.php/kespro/article/view/8013

Mariana, D., Wulandari, D., \& Padila, P. (2018). Hubungan Pola Makan dengan Kejadian Anemia pada Ibu Hamil di Wilayah Kerja Puskesmas. Jurnal Keperawatan Silampari, 1(2), 108-122. https://doi.org/10.31539/jks.v1i2.83

Musni, M., \& Malka, S. (2020). Hubungan Peran Orang Tua dan Perilaku Pacaran dengan Kejadian Kehamilan pada Remaja di Desa Melle Kab. Bone. Jurnal Ilmiah Kesehatan Diagnosis, 15(1), 14-18. http://jurnal.stikesnh.ac.id/index.php/jikd/article/view/127

Ningsih, D. P., \& Rahmadi, D. S. (2020). Dampak Pernikahan Dini di Desa Keruak Kecamatan Keruak Kabupaten Lombok Timur. Jurnal Ilmiah Mandala Education, 6(2), 404-414. DOI: 10.36312/jime.v6i2.1452

Padila, P., Panzilion, P., Juli, A., Nurhayati, N., \& Harsismanto, J. (2021). Pengalaman Ibu Usia Remaja Melahirkan Anak di Masa Pandemi COVID-19. Journal of Telenursing (JOTING), $3(1)$ 63-72. https://doi.org/https://doi.org/https://doi.org/10.31539/joting.v3i1.2075

Pemerintah Provinsi Bengkulu, P. (2020). Dinas Kesehatan Provinsi Bengkulu. https://bengkuluprov.go.id/tag/dinas-kesehatan-provinsi-bengkulu/

PKBI. (2020). Perkumpulan Keluarga Berencana Indonesia. https://caribengkulu.com/carikomunitas/perkumpulan-keluarga- berencana-indonesiaprov-bengkulu.html

Pradnyani, P. E., Ranitadewi, I. N., Luh, N., Purni, E., Febriana, F., Resmiadi, N. L., \& Utami, A. P. (2020). Sikap Remaja di 10 Provinsi Indonesia Terkait Perilaku Seksual Pada Masa Pandemi COVID-19. Jurnal IAKMI, 1-8. http://jurnal.iakmi.id/index.php/FITIAKMI/article/view/46

Pratiwi, B. A., Angraini, W., Padila, P., Nopiawati, N., \& Yandrizal, Y. (2019). Analisis Pernikahan Usia Dini di Kabupaten Bengkulu Tengah Tahun 2017. Jurnal Kesmas Asclepius, 1(1), 14-24. https://doi.org/10.31539/jka.v1i1.575

Purwanto, A., Pramono, R., Asbari, M., Santoso, P. B., Wijayanti, L. M., Choi, C. H., \& Putri, R. S. (2020). Studi Eksploratif Dampak Pandemi COVID-19 terhadap Proses Pembelajaran Online di Sekolah Dasar. EduPsyCouns: Journal of Education, Psychology and Counseling, 2(1), 1-12. https://ummaspul.ejournal.id/Edupsycouns/article/view/397 
Sartika, A., Oktarianita, O., \& Padila, P. (2021). Penyuluhan terhadap Pengetahuan Remaja tentang PKPR. Journal of Telenursing (JOTING), 3(1), 171-176. https://doi.org/https://doi.org/https://doi.org/10.31539/joting.v3i1.2192

Setyaningsih, M. M., \& Sutiyarsih, E. (2020). Faktor-Faktor Determinan yang Melatar Belakangi Kehamilan Remaja di Desa Pandansari Kecamatan Poncokusumo Kabupaten Malang. Jurnal Ners dan Kebidanan (Journal of Ners and Midwifery), 7(2), 247-255. https://doi.org/10.26699/jnk.v7i2.art.p247-255

Widyaningsih, P. A. I. (2021). Karakteristik Ibu Hamil yang Melahirkan Bayi Berat Lahir Rendah di Unit Pelaksana Teknis Daerah Puskesmas Sukawati II Gianyar. Poltekkes Denpasar. http://repository.poltekkes-denpasar.ac.id/7499/

Zakiah, U. (2020). Gambaran Kehamilan Remaja Ditinjau dari Umur, Penyebab Kehamilan dan Kontak Pertama dengan Tenaga Kesehatan di Wilayah Kerja Puskesmas Sikumana Kota Kupang. CHMK Midwifery Scientific Journal, 3(January 2018), 128133. http://cyber-chmk.net/ojs/index.php/bidan/article/view/767 